\title{
Applicability of Static Supercritical Carbon Dioxide Extraction in Biogeochemical Characterization of Oil Shales
}

\author{
Hans Luik*, Lea Luik, Vilja Palu, Galina Sharayeva, Andre Gregor \\ Laboratory of Oil Shale and Renewables Research, Tallinn University of Technology, \\ Tallinn, Estonia \\ Email: "hans.luik@ttu.ee
}

Received November 24, 2013; revised December 27, 2013; accepted January 5, 2014

Copyright (C) 2014 Hans Luik et al. This is an open access article distributed under the Creative Commons Attribution License, which permits unrestricted use, distribution, and reproduction in any medium, provided the original work is properly cited. In accordance of the Creative Commons Attribution License all Copyrights (C) 2014 are reserved for SCIRP and the owner of the intellectual property Hans Luik et al. All Copyright (C) 2014 are guarded by law and by SCIRP as a guardian.

\section{ABSTRACT}

This study aimed at the assessment of applicability of static supercritical carbon dioxide extraction method (SFE) in biogeochemical characterization of oil shales as an alternative to the standard Soxhlet extration. A comparative investigation on yields and compositions of the solvent soluble bitumoids and their constituents extracted from Estonian Kukersite and Dictyonema oil shales by using Soxhlet extraction method (SEM) and static $\mathrm{CO}_{2}$ supercritical fluid extraction in an autoclave at varied subpyrolysis temperatures was carried out. Resulting from TLC- and GC-MS-analyses, aliphatic and aromatic hydrocarbons and neutral oxygen compounds were separated and identified. For the first time, in the composition of the Kukersite bitumoid, homologous series of $n$-alkanones-3 to $n$-alkanones- 7 were detected. The extracts obtained were similar in both group and individual composition, and geochemical parametres calculated on the basis of aliphatic hydrocarbons including that made static SFE applicable to geochemical investigation of oil shales.

\section{KEYWORDS}

\section{Oil Shale; Bitumoid; Supercritical Extraction; Soxhlet Extraction; Geochemical Parametres}

\section{Introduction}

Oil shales in their variety have formed as a result of fossilization and sedimentation of marine and terrestrial biomass during millions of years. Maintained to a certain extent, their biogeochemical memory from time immemorial, oil shales in their variety consist of the fragments of ancient relic material in polymerized steric structure formed during fossilization, recognizable and investigable by analytical techniques. Oil shales are characterised by varied contents of the fossilized organic matter (OM) disproportionated between insoluble and soluble portions. Kerogen, making up the bulk of dispersed organic matter, is characterised as insoluble in organic solvents OM. Another part of the OM is not incorporated to the structure of kerogen and can be separated from oil shale matrix by using low-boiling solvents as extractables (bitu-

\footnotetext{
*Corresponding author.
}

moid). The latter can be observed as a mobile phase inside a macromolecular network containing various biomarkers for elucidating the genesis of the OM in oil shale and the degree of its maturity. The composition of both insoluble kerogen and soluble bitumoid represents the source of geochemical information on the biogenic precursors of $\mathrm{OM}$ and transformation of the latter in the Earth's crust. Structural constituents of the kerogen are attainable to the analytical investigation only after thermochemical destruction and oil formation occurring usually at the temperatures of $350^{\circ} \mathrm{C}-500^{\circ} \mathrm{C}$. Besides, pyrolysis is applicable for obtaining adequate feedback with initial matter via splinters formed from it during pyrolysis and provides reliable data on kerogen structure if the reaction mechanism is known. Fischer assay pyrolysis, hydrous pyrolysis and hydropyrolysis most often have been used [1-4]. At the same time, characteristic fragments of the $\mathrm{OM}$ of oil shales are readily transferable to 
the bitumoid composition as compounds of different chemical classes using solid-liquid Soxhlet extraction (SEM) with low-boiling solvents and their mixtures at boiling temperatures and that is why it is used as a classic method for extraction of analytes from solid materials [5,6]. SEM still remains a standard technique to which the performance of modern extraction techniques is compared. The most serious disadvantages of SEM are long extraction time required and a large amount of toxic solvents wasted. These drawbacks support the development for better and efficient techniques, and an intensive research on different modifications has been carried out in order to overcome the main disadvantages of conventional SEM. Available modifications include automated SEM, focused microwave-assisted SEM, high pressure SEM and fluidized bed extraction [7]. Rather little effects than essential advantages were observed. In [8], solvents of different polarities as methanol, acetonitrile, acetone, methylene chloride, tetrahydrofuran, toluene and hexane were used, and the authors became convinced that the yields of extractables from different oil shales at room temperature were in time lower compared with SEM depending differently on the nature of the solvent. In the same work, dynamic SFE was demonstrated as effective for the isolation of substances of medium molecular weight and relatively low polarity. This method was tested for the geochemical investigation of sapropelites in [9].

Introducing supercritical carbon dioxideas fluid offers several advantages over conventional solvent extraction. $\mathrm{CO}_{2}$ is noncombustible, nontoxic and inexpensive as a solvent having low polarity. Its critical parameters $\left(\mathrm{t}_{\mathrm{cr}}=\right.$ $31.1^{\circ} \mathrm{C}, \mathrm{p}_{\mathrm{cr}}=7.38 \mathrm{MPa}$ ) are easily accessible. Due to the capacity of supercritical carbon dioxide to penetrate into porous media, the method seems to be prospective for the recovery of the soluble components in oil shale. Due to the low critical temperature of $\mathrm{CO}_{2}$, SFE like SEM leaves the most of kerogen matrix untouched and brings out the soluble matter trapped in the shale matrix. Carbon dioxide has a higher diffusivity and lower viscosity compared to liquid solvents, which should result in improved mass transfer properties during extraction. The solvent strength of SFE is dependent on its temperature and pressure, which can easily be manipulated to extract certain classes of compounds [10]. In [11], SFE for the extraction of polychlorinated biphenyls from algae samples was used.

It has been reported that, in oil shales, dynamic extractions with pure supercritical carbon dioxide in a flow reactor, mainly $n$-alkanes, were extracted while addition of modifiers as methanol or ionic liquids slightly increased extract yield and enriched its composition with other compounds [8,12].

Estonian Kukersite and Dictyonema oil shales formed in Lower Paleozoic belong to the most ancient ones in the world. The source material of both kerogens is of marine origin. Kukersite is characterised by an extremely low bitumoid content arising from its allochthonous origin and sedimentation under conditions of oxidizing atmosphere. Dictyonema oil shale which proceeded formation under the influence of sulfate-reducing microbes, contains less kerogen and yields considerably more extractables in SEM [13]. Main structural units of OM of sapropelites and their pyrolysis oils are straight and, in less measure, branched carbon chains, precursors of which were fatty acids and isoprenoid structures, respectively, being transformed to bitumoid and kerogen pyrolysis oil composition as paraffins, olefins and ketones [14, 15]. The corresponding structures of oil shale have been formed by fossilization of the most stable components (fatty acids) of biological source material. The hydrocarbon chains in ancient oil shale kerogens have mainly odd carbon numbers [9,14]. Dictyonema oil shale is a brown lithified clay belonging to the formation of black shales of sapropelic origin, whose OM is rich in heteroatoms $[16,17]$.

The aim of the present work is to determine and compare the extraction yields and compositions resulting from static SFE and SEM of oil shales, and on the basis of geochemical parametres calculated estimate the applicability of the SEF as an alternative method to the biogeochemical studies of oil shales.

\section{Samples}

Air-dry, finely powdered $(0.04-0.1 \mathrm{~mm})$ and homogenised Kukersite and Dictyonema oil shale samples characterised in Table 1 were used as initial feedstocks.

One can see that the oil shales under investigation largely differ by $O M^{\mathrm{d}}$ content, kerogen chemical composition and pyrolysis oil yield.

\section{Experimental: Methods and Analysis}

Oil shale samples were submitted to the static SFE at three different temperatures in a rocking $500 \mathrm{~cm}^{3}$ stainless steel batch autoclave supplied with a manometer and gas valves. Starting with $100 \mathrm{~g}$, the same portion of oil shale was extracted consequtively at 40,100 , and $150^{\circ} \mathrm{C}$ and initial carbon dioxide pressure 9 MPa during 2 hours. At the end of heating, the system was cooled down to the ambient temperature. Then the gas amount was released from the autoclave via gas valve and the autoclave was opened. The extractables formed were diluted with diethyl ether and separated after each step. Diethyl ether was evaporated and the extract yields were determined by weight analysis.

Also, exhaustive SEM using chloroform and benzenemethanol mixture was carried out with obtaining bitu- 
Table 1. Characterization of oil shales (\%).

\begin{tabular}{ccc}
\hline Characteristic & Kukersite & Dictyonema \\
\hline Age, million years & 460 & 480 \\
Mineral matter & Carbonates & Aluminosilicates \\
Analytical moisture, $W^{\mathrm{a}}$ & 0.6 & 1.4 \\
Ash (per dry mass), $A^{\mathrm{d}}$ & 37.2 & 81.2 \\
$\mathrm{CO}_{2}$ of carbonates (per dry mass), & 12.3 & 2.8 \\
$\left(\mathrm{CO}_{2}\right)^{\mathrm{d}}$ & 50.5 & 16.0 \\
Dry organic matte, $O M^{\mathrm{d}}$ & & \\
Elemental composition of $O M^{\mathrm{d}}:$ & & 73.02 \\
$\mathrm{C}$ & 79.32 & 9.19 \\
$\mathrm{H}$ & 9.50 & 2.66 \\
$\mathrm{~N}+\mathrm{S}$ & 0.30 & 15.12 \\
$\mathrm{O}$ & 10.88 & 1.510 \\
$\mathrm{H} / \mathrm{C}$ molar ratio & 1.437 & 0.155 \\
O/C molar ratio & 0.103 & 15.1 \\
\hline Fischer Assay oil yield & 61.0 & \\
\hline
\end{tabular}

moids A and C, respectively.

Chemical composition of extracts was investigated by using thin-layer chromatography (TLC) and gas-chromatographic-mass-spectroscopic (GC-MS) methods.

Extracts were separated into groups of compounds by preparative TLC. Plates, $24 \times 24 \mathrm{~cm}$ coated with a $2 \mathrm{~mm}$ silica gel (60 $\mu \mathrm{m}$, Fluka) were used and $500 \mathrm{mg}$ samples were analysed. $n$-Hexane as the eluent was used. As a result the fractions of aliphatic hydrocarbons, monocyclic aromatic hydrocarbons, polycyclic aromatic hydrocarbons, neutral heteroatomic compounds and high polar heteroatomic compounds were separated. The individual composition of compounds separated was analysed by GC-MS in $30 \mathrm{~m}$ capillary columns ZB-5 and HP-5MS. Identification was performed by the monitoring of the key ions.

\section{Results and Discussion}

\subsection{Extraction Yields and Group Composition of the Extracts}

Yields of extractables (bitumoids) eluated from oil shales by SEM and stepwise static SFE as well as their group composition separated by TLC are represented in Tables 2 and 3. Kukersite gives in both processes lower extract yields compared with Dictyonema oil shale.

One can see that total bitumoid yields obtained as summarized yields of bitumoids A and C from SEM of Kukersite and Dictyonema oil shales using chloroform and benzene-methanol mixture consequtively were re- covered as $0.79 \%$ and $4.88 \%$. Stepwise SFE of Kukersite triplicated the yield of extractables while that of Dictyonema oil shale gave extractables less by $30 \%$ compared with SEM. It is noteworthy that SFE of Kukersite resulted in higher yields of extractables than those of bitumoids $\mathrm{A}$ and $\mathrm{C}$ summarized at every process temperature, i.e. 40,100 and $150^{\circ} \mathrm{C}$. SFE of the Dictyonema oil shale at $40^{\circ} \mathrm{C}$ resulted roughly in the same extractables yield as that of bitumoid A. So, the extractables obtained at 100 and $150^{\circ} \mathrm{C}$ can represent an additional source of geochemical information in Kukersite case and observed as an alternative to the bitumoid C in Dictyonema case.

Group compositition data in Tables 2 and 3 show that all extracts were represented by the same groups of hydrocarbons and heteroatomic compounds despite originated from different oil shales and produced resulting from solvent or fluid processes. Heteroatomic compounds are prevailing over hydrocarbons, particularly in Soxhlet extracts where the content of those amounts to $88 \%$ - 92\%. Among heteroatomic compounds the polar ones, and in the composition of hydrocarbons the aliphatic ones are prevailing over neutral and aromatic ones, respectively. It can be seen that SFE compared with SEM produces considerably more hydrocarbons and less high polar heteroatomic compounds.

\subsection{Extraction Efficiency and Selectivity}

Extraction efficiency of SEM and SFE with regard to different compound groups determined is represented in Tables 4 and 5. Extraction efficiency depends on both process variables as temperature, pressure, duration, solvent type and chemical composition of the source matter.

Higher in times efficiencies were obtained on account of certain compounds groups transformed to the extractables composition resulting from SFE. One can see that SFE performed already at $40^{\circ} \mathrm{C}$, i.e. the lowest temperature used results in considerably higher production of aliphatic, mono- and polycyclic aromatic hydrocarbons and neutral heteroatomic compounds from both Kukersite and Dictyonema oil shales than SEM with liquid chloroform. Distinction between SFE and SEM efficiences becomes particularly evident when those compounds in extracts yielded from oil shales at $40^{\circ} \mathrm{C}$ are compared with their yields in summarized bitumoids $\mathrm{A}$ and C. Further extraction at the temperatures $100^{\circ} \mathrm{C}$ and $150^{\circ} \mathrm{C}$ yielded additive portions of hydrocarbons and neutral heteroatomic compounds and that is why efficiency of different compound classes on the bases of summarized extract $\left(\sum 150\right)$ with that in total bitumoid (bitumoids A + C) would be compared to obtain comparable and reliable data. Such comparison can be seen in Tables 4 and 5 demonstrating amplified regularities described above. Extraction efficiency of the same com- 
Table 2. Yields (1-mg/g, 2-\% per OM) and group composition (relative \%) of SEM extracts.

\begin{tabular}{|c|c|c|c|c|c|c|c|}
\hline \multirow{2}{*}{ SEM } & \multicolumn{2}{|c|}{ Yield } & \multirow{2}{*}{$\begin{array}{c}\text { Aliphatic } \\
\text { hydro-carbons }\end{array}$} & \multirow{2}{*}{$\begin{array}{l}\text { Mono-cyclic } \\
\text { aromatic } \\
\text { hydro-carbons }\end{array}$} & \multirow{2}{*}{$\begin{array}{c}\text { Poly-cyclic } \\
\text { aromatic } \\
\text { hydro-carbons }\end{array}$} & \multirow{2}{*}{$\begin{array}{c}\text { Neutral } \\
\text { hetero-atomic } \\
\text { com-pounds }\end{array}$} & \multirow{2}{*}{$\begin{array}{l}\text { High polar } \\
\text { hetero-atomic } \\
\text { com-pounds }\end{array}$} \\
\hline & 1 & 2 & & & & & \\
\hline \multicolumn{8}{|c|}{ Kukersite } \\
\hline Bitumoid A & 1.63 & 0.48 & 19.9 & 7.6 & 2.8 & 14.6 & 55.1 \\
\hline Bitumoid C & 1.03 & 0.31 & 10.1 & 1.6 & 0.7 & 1.2 & 86.4 \\
\hline$\sum \mathrm{A}+\mathrm{C}^{*}$ & 2.66 & 0.79 & 16.2 & 5.3 & 2.0 & 9.3 & 67.2 \\
\hline \multicolumn{8}{|c|}{ Dictyonema } \\
\hline Bitumoid A & 2.80 & 1.75 & 7.5 & 1.5 & 3.0 & 5.5 & 82.5 \\
\hline Bitumoid C & 5.00 & 3.13 & 5.6 & 0.6 & 0.9 & 1.3 & 91.6 \\
\hline$\sum \mathrm{A}+\mathrm{C}^{*}$ & 7.80 & 4.88 & 6.3 & 0.7 & 1.9 & 2.8 & 88.3 \\
\hline
\end{tabular}

*After extraction with chloroform and treatment of the extraction residue with $10 \% \mathrm{HCl}$.

Table 3. Yields (1-mg/g, 2-\% per OM) and group composition (relative \%) of SFE extracts.

\begin{tabular}{|c|c|c|c|c|c|c|c|}
\hline \multirow{2}{*}{ SFE temperature, ${ }^{\circ} \mathrm{C}$} & \multicolumn{2}{|c|}{ Yield } & \multirow{2}{*}{$\begin{array}{c}\text { Aliphatic } \\
\text { hydro-carbons }\end{array}$} & \multirow{2}{*}{$\begin{array}{c}\text { Mono-cyclic } \\
\text { aromatic } \\
\text { hydro-carbons }\end{array}$} & \multirow{2}{*}{$\begin{array}{c}\text { Poly-cyclic } \\
\text { aromatic } \\
\text { hydro-carbons }\end{array}$} & \multirow{2}{*}{$\begin{array}{l}\text { Neutral } \\
\text { hetero-atomic } \\
\text { com-pounds }\end{array}$} & \multirow{2}{*}{$\begin{array}{l}\text { High polar } \\
\text { hetero-atomic } \\
\text { com-pounds }\end{array}$} \\
\hline & 1 & 2 & & & & & \\
\hline \multicolumn{8}{|c|}{ Kukersite } \\
\hline 40 & 4.21 & 0.82 & 20.1 & 9.7 & 18.2 & 14.2 & 37.8 \\
\hline 100 & 2.94 & 0.57 & 17.6 & 10.9 & 13.2 & 21.5 & 36.8 \\
\hline 150 & 5.00 & 0.97 & 18.9 & 2.6 & 10.6 & 8.6 & 59.3 \\
\hline$\sum 150$ & 12.15 & 2.36 & 19.1 & 7.0 & 13.9 & 13.6 & 46.4 \\
\hline \multicolumn{8}{|c|}{ Dictyonema } \\
\hline 40 & 2.34 & 1.47 & 26.4 & 6.2 & 9.6 & 20.6 & 37.2 \\
\hline 100 & 2.40 & 1.51 & 20.2 & 4.1 & 11.8 & 23.9 & 40.0 \\
\hline 150 & 1.06 & 0.67 & 30.8 & 2.2 & 20.1 & 22.8 & 24.1 \\
\hline$\sum 150$ & 5.80 & 3.65 & 25.3 & 4.6 & 12.2 & 22.2 & 35.7 \\
\hline
\end{tabular}

Table 4. Extraction efficiency of different compound groups resulting from SEM (mass \%o).

\begin{tabular}{|c|c|c|c|c|c|c|}
\hline SEM & $\begin{array}{c}\text { Aliphatic } \\
\text { hydro-carbons }\end{array}$ & $\begin{array}{l}\text { Mono-cyclic aromatic } \\
\text { hydro-carbons }\end{array}$ & $\begin{array}{l}\text { Poly-cyclic aromatic } \\
\text { hydro-carbons }\end{array}$ & $\begin{array}{l}\text { Neutral hetero-atomic } \\
\text { com-pounds }\end{array}$ & $\begin{array}{l}\text { High polar hetero-atomic } \\
\text { com-pounds }\end{array}$ & Total extract \\
\hline \multicolumn{7}{|c|}{ Kukersite } \\
\hline Bitumoid A & 0.96 & 0.36 & 0.13 & 0.70 & 2.64 & 4.79 \\
\hline Bitumoid C & 0.31 & 0.05 & 0.02 & 0.04 & 2.68 & 3.10 \\
\hline$\sum \mathrm{A}+\mathrm{C}$ & 1.27 & 0.41 & 0.15 & 0.74 & 5.32 & 7.89 \\
\hline \multicolumn{7}{|c|}{ Dictyonema } \\
\hline Bitumoid A & 1.31 & 0.29 & 0.50 & 0.96 & 14.44 & 17.50 \\
\hline Bitumoid C & 1.75 & 0.19 & 0.28 & 0.41 & 28.67 & 31.30 \\
\hline$\sum \mathrm{A}+\mathrm{C}$ & 3.06 & 0.48 & 0.78 & 1.37 & 43.11 & 48.80 \\
\hline
\end{tabular}


Table 5. Extraction efficiency of different compound groups resulting from SFE (mass \%o).

\begin{tabular}{ccccccc}
\hline SFE temperature, ${ }^{\circ} \mathrm{C}$ & $\begin{array}{c}\text { Aliphatic } \\
\text { hydro-carbons }\end{array}$ & $\begin{array}{c}\text { Mono-cyclic aromatic } \\
\text { hydro-carbons }\end{array}$ & $\begin{array}{c}\text { Poly-cyclic aromatic } \\
\text { hydro-carbons }\end{array}$ & $\begin{array}{c}\text { Neutral hetero-atomic High polar hetero-atomic } \\
\text { com-pounds }\end{array}$ & Total extract \\
com-pounds
\end{tabular}

pound groups from Dictyonema oil shale surpasses that of Kukersite.

Generalizing, SFE yields from both oil shales mainly various hydrocarbons and neutral heteroaromic compounds while SEM produces lots of high polar heteroatomic compounds the efficiencies of extraction always being higher for Dictyonema oil shale. Productivities of Soxhlet extractor and batch autoclave in case of Dictyonema and Kukersite oil shale were 10 - 50 and 120 - 200 $\mathrm{mg} / \mathrm{h}$, respectively. SFE leads to higher productivities at lower temperature and shorter process duration.

\subsection{Composition of the Extracts}

According to the GC-MS data the compounds having long straight alkyl chains, are the most common in all extracts. In Figure 1 the composition of aliphatic hydrocarbons is depicted and one can see that $n$-alkanes distinctly prevail over isoalkanes. Among monoaromatic hydrocarbons homologoues $n$-alkyl benzenes with maximum 10 carbon atoms in side chain were identified (see Figure 2). Homologous $n$-alkanes $\mathrm{C}_{11}-\mathrm{C}_{25}$ and regular isoprenoids $(\mathrm{m} / \mathrm{z} 71)$, alkylcyclohexanes ( $\mathrm{m} / \mathrm{z} 83)$, alkylbenzenes $(\mathrm{m} / \mathrm{z}$ 92), naphthalene $(\mathrm{m} / \mathrm{z} 128)$, methyl-, dimethyl-, trimethyl- and tetramethylnaphthalenes $(\mathrm{m} / \mathrm{z}$ 142, m/z 156, m/z 170 and m/z 184, respectively), $n$ alkanones-2 and symmetric $n$-alkanones (m/z 58), containing maximum 17 carbon atoms in the Kukersite extracts were found. The regularities of distribution and maximum length of hydrocarbonaceous chains was found differing depending on the extract origin.

For the first time, in the composition of Kukersite oil shale extraction products homologous series of $n$-alkanones-3, $n$-alkanones- 4 and $n$-alkanones- $5, n$-alkanones6 and $n$-alkanones- 7 were detected. As it can be seen in Figure 3, identification of the latters is complicated be-

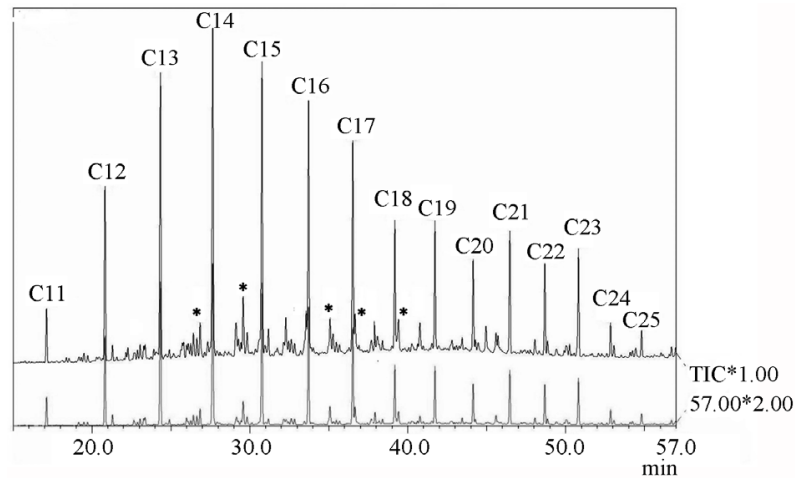

Figure 1. TIC of the $n$-alkanes $\mathrm{C}_{11}-\mathrm{C}_{25}$ and regular isoprenoids $(*)$ farnesane, 2,6,10-trimethyltridecane, norpristane, pristane, phytane originated from Kukersite bitomoid A.

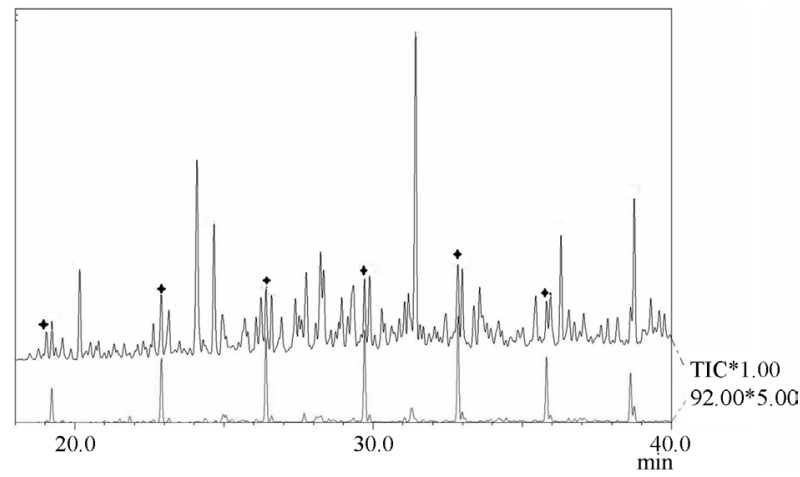

Figure 2. TIC of $n$-alkyl benzenes $(\diamond, \mathrm{m} / \mathrm{z} 92)$ in the monoaromatic hydrocarbons fraction of Kukersite SEM extract.

cause those are characterized with the same $\mathrm{m} / \mathrm{z}$ values as joint peak.

Dictyonema extracts were characterized by the same homologous series of compounds having, in most instances, longer alkyl chains amounting as an absolute 


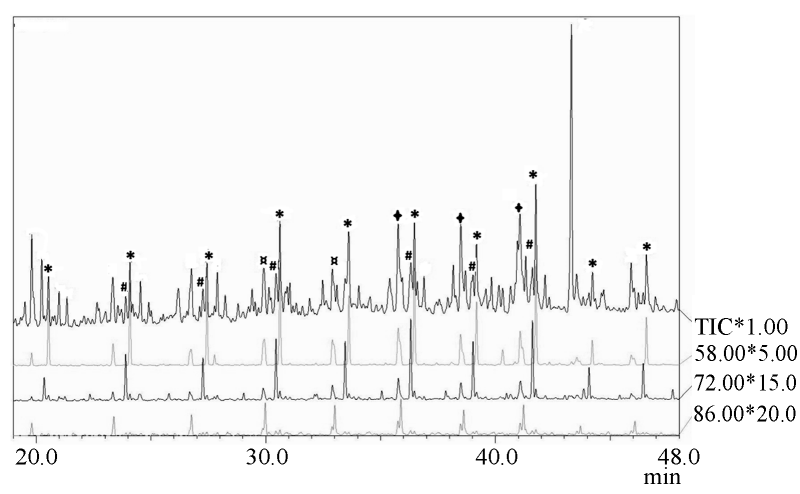

Figure 3. TIC of $\boldsymbol{n}$-alcanones in the neutral heteroatomic fraction of the Kukersite SFE extract: $n$-alcanones- $2(*, m / z$ 58); $n$-alcanones-3 (\#, m/z 72); $n$-alcanones-4 and $n$ - alcanones-5 (a, m/z 86); $n$-alcanones-6 and $n$-alcanones-7 $(\stackrel{\leftrightarrow}{\text {, }}$ $\mathbf{m} / \mathbf{z ~ 7 1 ) . ~}$

maximum to 31 in $n$-alkanes. In addition to those in $\mathrm{Ku}-$ kersite extracts, besides phenantrene and its alkyl derivatives, carboxylic acids and esters were identified in Figure 4. The latter were found when bitumoid $\mathrm{C}$ as a whole, characterized by as high as $91.6 \%$ content of high polar heteroatomic compounds, was subjected to the GS-MS analysis.

\subsection{Geochemical Parametres}

Below, in Tables 6 and 7 organic geochemical data of the extracts are represented.

Although there are some diver gencies in the values of parametres often used in geochemical investigation of oil shales and other caustobioliths depending on extraction conditions, the main tendencies and specific features of the oil shale under investigation can be described in like manner. $n$-Alkanes from Kukersite are characterized by odd ones predominance in their relative distribution, characaterized by carbon predominance index (CPI) that being higher than 1 what is characteristic for biogenic $n$-alkanes being preserved in immature OM. Predominance of the odd homologouesare characteristic in side chains of $n$-alkylbenzenes, $n$-alkylcyclohexanes and $n$ alcanones series as well. According to the CPI values of hydrocarbons originated from Dictyonema oil shale originated the content of odd carbon homologoues is equal to those of even numbered. Pristane-to-phytane ratio is higher than 1 for structures originated from Kukersite while in Dictyonema shale this value is near to 1 . The extracts obtained at higher SFE temperature are rich in high-molecular $n$-alkanes and some parallels with the bitomoid $\mathrm{C}$ can be drawn.

Juxtaposing the respective parametres, one can find similar regularities between bitumoid A and SFE $40^{\circ} \mathrm{C}$ extract and bitumoid $\mathrm{C}$ and SFE at $150^{\circ} \mathrm{C}$. At the same time one can see in Tables 6 and 7 that summarized ex-

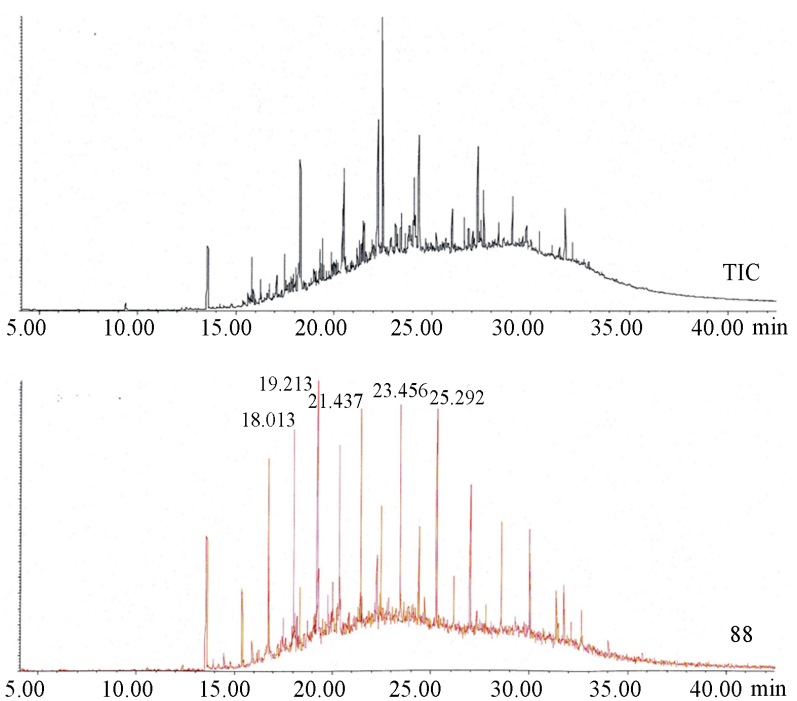

Figure 4. TIC of bitumoid C from SEM of Dictyonema oil shale: carboxylic acids and esters (m/z 60 and m/z 88).

tracts from SFE at $40^{\circ} \mathrm{C}, 100^{\circ} \mathrm{C}$ and $150^{\circ} \mathrm{C}$ can be characte- rized as less different than bitumoid $\mathrm{A}$ and $\mathrm{C}$ between themselves. In dilemma, either anyone of the selected extracts or summarised SFE and SEM extracts should be used to characterize oil shale composition more ade- quately total extracts would be recommended.

These results lead to the consequence that the composition and relative distribution of $n$-alkanes do not change significantly when SFE of oil shale is used instead of SEM.

\section{Conclusions}

Stepwise SFE of the Kukersite and Dictyonema oil shales in static autoclaving conditions, representing thermal dissolution at subpyrolysis temperatures, was applied alternatively to conventional Soxhlet extraction (SEM).

Investigation on both group and individual composition and comparison of the geochemical parametres calculated on the basis of SEM and SFE extracts of the oil shales showed similarity, thus indicating the applicability of SFE to more effective separation of bitumoid components compared with laborious SEM.

Homologous $n$-alkanes, alkylmonoarenes, alkylpolyarenes and alkylalkanones easily extracted by SFE were identified, and new compounds as $n$-alkanones-3, n-alkanones-4, n-alkanones-5, $n$-alkanones- 6 and $n$-alkanones7 were found in SFE extracts.

This process can be observed as supercritical thermal dissolution performed stepwise.

\section{Acknowledgements}

The study was supported by the Estonian Research Council: project SF0140028s09, grant No.9331 and EU 
Table 6. Geochemical parameters calculated on the basis of GC-MS data for Kukersite extracts.

\begin{tabular}{|c|c|c|c|c|c|c|c|}
\hline \multirow{2}{*}{ Parameter } & \multicolumn{3}{|c|}{ SFE } & \multicolumn{4}{|c|}{ SEM } \\
\hline & $40^{\circ} \mathrm{C}$ & $100^{\circ} \mathrm{C}$ & $150^{\circ} \mathrm{C}$ & $\sum 150^{\mathrm{a}}$ & Chloroform & Benzene and methanol mixture & Bitumoid A + $\mathrm{C}^{\mathrm{a}}$ \\
\hline CPI of $n$-alkanes & 1.13 & 1.14 & 0.97 & 1.12 & 1.18 & 1.28 & 1.20 \\
\hline$<\mathrm{C}_{17} / \geq \mathrm{C}_{17}$ & 0.21 & 0.28 & 0.40 & 0.30 & 0.46 & 0.27 & 0.30 \\
\hline Pristane/phytane & 1.01 & 1.10 & 1.10 & 1.10 & 1.50 & 1.20 & 1.25 \\
\hline Pristane + phytane $/ n-\mathrm{C}_{17}+n-\mathrm{C}_{18}$ & 0.17 & 0.14 & 0.21 & 0.18 & 0.40 & 0.44 & 0.41 \\
\hline Pristane $/ n-C_{17}$ & 0.13 & 0.09 & 0.20 & 0.15 & 0.36 & 0.47 & 0.39 \\
\hline Phytane/n-C 18 & 0.25 & 0.22 & 0.22 & 0.23 & 0.50 & 0.30 & 0.38 \\
\hline
\end{tabular}

${ }^{\mathrm{a} C a l c u l a t e d}$ weighted average values.

Table 7. Geochemical parameters calculated on the basis of GC-MS data for Dictyonema extracts.

\begin{tabular}{|c|c|c|c|c|c|c|c|}
\hline \multirow{2}{*}{ Parameter } & \multicolumn{3}{|c|}{ SFE } & \multicolumn{4}{|c|}{ SEM } \\
\hline & $40^{\circ} \mathrm{C}$ & $100^{\circ} \mathrm{C}$ & $150^{\circ} \mathrm{C}$ & $\sum 150^{\mathrm{a}}$ & Chloroform & Benzene and methanol mixture & Bitumoid $\mathrm{A}+\mathrm{C}^{\mathrm{a}}$ \\
\hline CPI of $n$-alkanes & 0.96 & 1.05 & 0.92 & 0.98 & 1.03 & 0.98 & 1.00 \\
\hline$<\mathrm{C}_{17} / \geq \mathrm{C}_{17}$ & 0.38 & 0.47 & 0.40 & 0.40 & 0.26 & 0.21 & 0.23 \\
\hline Pristane/phytane & 0.84 & 0.91 & 1.15 & 1.01 & 1.00 & 1.02 & 1.01 \\
\hline Pristane + phytane $/ n-\mathrm{C}_{17}+n-\mathrm{C}_{18}$ & 0.42 & 0.40 & 0.81 & 0.50 & 0.46 & 0.52 & 0.49 \\
\hline Pristane $/ n-\mathrm{C}_{17}$ & 0.38 & 0.37 & 0.94 & 0.51 & 0.50 & 0.62 & 0.57 \\
\hline Phytane $/ n-\mathrm{C}_{18}$ & 0.54 & 0.43 & 0.70 & 0.54 & 0.43 & 0.44 & 0.44 \\
\hline
\end{tabular}

${ }^{\text {a }}$ Calculated weighted average values.

Structural Funds: project 3.2.0501.1-0023.

\section{REFERENCES}

[1] I. Klesment, "Aliphatic Carbon Chains of Oil Shale Kerogen," Proceedings of the Academy of Sciences of the Estonian SSR, Vol. 24, No. 2, 1975, pp. 123-129.

[2] T. L. Robl, A. E. Bland, D. W. Koppenaal and L. S. Barron, "Geochemistry of Oil Shales in Eastern Kentucky," In: F. P. Miknis and J. F. McKay, Eds., Geochemistry and Chemistry of Oil Shales, ACS Symposium Series 230, American Chemical Society, Washington DC, 1983, pp. 159-180.

[3] T. Barth, "Similarities and Differences in Hydrous Pyrolysis of Biomass and Source Rocks," Organic Geochemistry, Vol. 30, No. 12, 1999, pp. 1495-1507. http://dx.doi.org/10.1016/S0146-6380(99)00121-7

[4] J. D. Rocha, S. D. Brown, G. D. Love and C. E. Snape, "Hydropyrolysis: A Versatile Technique for Solid Fuel Liquefaction, Sulphur Speciation and Biomarker Release,” Journal of Analytical and Applied Pyrolysis, Vol. 40-41, 1997, pp. 91-103. http://dx.doi.org/10.1016/S0165-2370(97)00041-7

[5] M. D. Luque de Castro and F. Priego-Capote, "Soxhlet Extraction: Past and Present Panacea," Journal of Chromatography A, Vol. 1217, No. 16, 2010, pp. 2388-2389. http://dx.doi.org/10.1016/j.chroma.2009.11.027

[6] K. Urov and A. Sumberg, "Characteristics of Oil Shales and Shale-Like Rocks of Known Deposits and Outcrops. Monograph,” Oil Shale, Vol. 16, No. 3, 1999, pp. 1-64.

[7] A. Zygler, M. Słomińska and J. Namieśnik, "Soxhlet Extraction and New Developments such as Soxtec," In: J.Pawliszyn, Ed., Comprehensive Sampling and Sample Preparation. Analytical Techniques for Scientists, Vol. 2, Theory of Extraction Techniques, 2012, pp. 65-82.

[8] M. Koel, S. Ljovin, K. Hollis and J. Rubin, "Using Neoteric Solvents in Oil Shale Studies," Pure and Applied Chemistry, Vol. 73, No. 1, 2001, pp. 153-159. http://dx.doi.org/10.1351/pac200173010153

[9] I. Klesment and E. Bondar, "Biogeochemical Aspects of Evolution of Sapropelites According to Data of Molecular Paleontology," Oil Shale, Vol. 14, No. 1, 1997, pp. 19-40.

[10] M. Allawzi, A. Al-Otoom, H. Allaboun, A. Ajlouni and F. Al Nseirat, " $\mathrm{CO}_{2}$ Supercritical Fluid Extraction of Jordanian Oil Shale Utilizing Different Co-Solvents," Fuel Processing Technology, Vol. 92, No. 10, 2011, pp. 20162023. http://dx.doi.org/10.1016/j.fuproc.2011.06.001

[11] M. O. Punin Crespo and M. A. Lage Yusty, “Comparison of Supercritical Fluid Extraction and Soxhlet Extraction for the Determination of PCBs in Seaweed Samples," Chemosphere, Vol. 59, No. 10, 2005, pp. 1407-1413. http://dx.doi.org/10.1016/j.chemosphere.2004.12.025 
[12] E. Bondar and M. Koel, "Application of Supercritical Fluid Extraction to Organic Geochemical Studies of Oil Shales,” Fuel, Vol. 77, No. 3, 1998, pp. 211-213. http://dx.doi.org/10.1016/S0016-2361(97)00188-9

[13] I. Klesment, "On the Genesis of the Baltic Oil Shales," Oil Shale, Vol. 2, No. 1, 1985, pp. 12-22.

[14] I. Klesment, "Investigation of Aliphatic Structures of Oil Shales by Pyrolysis and Chromatographic Methods," Journal of Analytical and Applied Pyrolysis, Vol. 2, No. 1, 1980, pp. 63-77.

http://dx.doi.org/10.1016/0165-2370(80)80046-5

[15] J. S. Sinninghe Damste and J. W. De Leeuw, "Analysis, Structure and Geochemical Significance of Organically-
Bound Sulphur in the Geosphere: State of the Art and Future Research,” Organic Geochemistry, Vol. 16, No. 4-6, 1990, pp. 1077-1101. http://dx.doi.org/10.1016/0146-6380(90)90145-P

[16] A. Loog, V. Petersell, J. Aruväli and M. Kalm, "Methods for the Determination of the Texture and Mineral Composition of the Dictyonema Shale,” Bulletin of the Geological Survey of Estonia, Vol. 8, 1998, pp. 32-36.

[17] R. Veski and V. Palu, "Investigation of Dictyonema Oil Shale and Its Natural and Artificial Transformation Products by a Vankrevelenogram,” Oil Shale, Vol. 20, No. 3, 2003, pp. 265-281. 